\title{
The Role of Multimedia in General and Economic Vocational Training
}

\author{
Ágnes S. Végh \\ Budapest Business School, \\ College of Commerce, Catering and Tourism
}

\section{SUMMARY}

The subject of my study is the methodological question of one of the topics of operation research as an application field of mathematics. The mathematics and operation research team of our institute aims to provide up to date knowledge to our students of both regular and distance education courses. Each topic has been allotted to a different teacher, thus my responsibilities include Networks and their economic application, and my ambition is to achieve increasingly good results teaching this subject. The distance education course of our college provides the opportunity to try a wide range of methodological methods.

\section{INTRODUCTION}

Our college has been running distance education courses since 1996. Due to increasing interest, we are constantly developing our instructional materials. Our lecture notes were published in 1998 (3), and in 1999 we successfully applied for the tender of the Nyitott Szakképzésért Alapítvány (Foundation for Open Vocational Training), which enabled us to develop multimedia educational material and to renew our computer pool. Since 1999 we recorded all operation research lectures with an amateur video camera. Both $\mathrm{mm}$ materials are popular among

distance education students. They are regularly sought after at the distance education information desk. Their popularity motivated our department to continue to develop instructional materials from our own resources.

\section{THE METHOD APPLIED}

Cooperating with the Computer Science team we came upon the Neobook 4 program package that edits and designs instructional programs. With the help of this package, our colleagues have the possibility to elaborate the given short units on their own, based on a sample program.

This was also the method I chose when transforming the already existing written lecture notes on the topic of networks and their economic application to $\mathrm{mm}$ means (this may be a slight exaggeration on my part!). I equally relied on Neobook 4 to create my instructional program. In several cases, I also needed my colleague's support, who's previously developed instructional program on WORD (2) was also at my disposal.

The difference between the time required for transformation according to Bernat (2) and the time used by myself is shown in the chart below.

\begin{tabular}{|l|l|}
\hline Transformation of the program & Transformation of the program \\
Estimated time of expert & Own experience \\
\hline Collection of new contents & Getting to know the sample program \\
2 days (10 working hours) & 0,5 day (3 working hours) \\
Collection of new contents \\
2 days (10 working hours)
\end{tabular}

Reference: own chart

It is evident, that due to insufficient know-how of programming, the creation of a so called program fragment, a chapter took 38 hours instead of the 20 hours estimated in advance. It took significantly longer to produce the different visuals and contents than it had been expected by the expert. The required time is naturally expected to shorten when working on the following chapter since the technique previously acquired can be re-used. Processing such modular material is favorable anyway, according to bibliography.

\section{THE ELABORATED TOPIC AND THE METHOD OF ELABORATION}

According to our theory, the thus compiled unit would provide the first part of the complex system involving the seven main subjects of operation research. The basis of the processing, as in the case of our lecture notes from 1998, is the work of the American authors Hillier-Lieberman: Bevezetés az operációkutatásba (Introduction to Operation Research). 


\subsection{The topic}

Originally, my intention was to expand the existing three topics of their work - the problems of the Shortest - Path, the Minimum Spanning Tree and the Maximum Flow, but for the time being, I have only dealt with the first two. I plan to insert the third topic along with the relevant, extremely significant and usable PERT-CPM method into the unit at a later time.

The accomplished material deals with one chapter, that on graphs. It's main goal is to draw the attention of students to the possible answers that may be given to questions and needs arising mainly from an economic point of view, after a short introduction and the review of basic terminology.

\subsection{Structural elements}

I managed to elaborate the material on four so called pages. These are not traditional pages, since the individual student is able to open the menu points appearing on each page, and to print the contents of the text and picture windows equipped with a scrolling bar. The table of contents can be found on each page to facilitate a fast switch between pages. Other constant visuals are the relevant Guide (what to do) and Quit icons, the main title and the page number. Images visible on the screen are on view in the appendix.

Changing the previously listed elements, altering the script during program modification imposed difficulties of various level. In several cases, personal assistance was required.

According to the basic theory, the first page is the introduction, with the objective of raising interest, establishing basic terminology and supplying a thesis. It is my view - and I thrive to achieve it through my contact classes as well - that professionals working in economic and other fields must have a grasp of basic human and exact scientific concepts. Achieving such a grasp of mathematical basic concepts is a long process and these bordering territories are especially convenient when emphasizing it's importance. After a short historical review, an outline of basic terminology can be seen in the window equipped with scrolling bar, in a printable form.

The contents of the following page are more varied. This page informs the students of the basic problem, supplies the framework, and makes the topic, within mathematical operation research, which may seem dry in the beginning, more digestible. With the help of the three buttons in the middle of the page the students can start watching three video films, the first of which is a piece on environment protection. The second and third films show possible solutions to the relevant problems indicated on the buttons, using a method that may be applied by the student using the concrete graph this time. Thus, the objective of the second page is problem raising and illustration.
The third page demonstrates the information and the algorithms that actually have to be mastered by the students, therefore this page is the most detailed. Opening the menu, seven twin-pages, so called slides, become visible. If we click on the various inscriptions, we can see that there is an image and a scrollable text belonging to them. Both are printable, depending on individual requirements. Naturally, the entire content of the text windows could not be shown on the images used as illustration, so they only demonstrate certain details of the material. When creating the program, my intentions were to present the material in sufficient detail so that the students have no need to turn to additional data and support. Two of the seven slides show the same basic graph and both windows of slide 6 are textual to present solutions with identical value.

The majority of students is likely to work with this page most frequently, since this provides the greatest support in acquiring the knowledge of algorithms that form the exam material. It is important to make the level and the method of examination clear from the beginning. To achieve this goal the students of our college receive sample exams, or can download support material from the Internet. The exercises given and examined in the topic of graphs come from these two topics.

As in the case of each chapter of our lecture notes, the conclusion of the instructional program is a self-check test. On page four, students are able to measure how thoroughly and efficiently they read and acquired the extract on the topic of graphs. The student has three choices, indicated by selecting from the menu on the right side of the screen, and can either choose the questions or the exam. In the first case one receives three or ten questions, and can use help if necessary, as indicated by the Help icon. Given the student chose the exam, the Help icon is deleted and after having answered the ten questions, the computer gives the student's result, warning of possible defficiencies or acknowledging the successful mastering of the material. After each individual response, there is audio-visual feedback on the correctness of the answer.

Although the above page functions, I find this the most problematic and therefore in need of correction. The student has to write the answer in the blank, gray field visible on the screen. The computer only accepts the answer if it's wording is identical to the letter to the answer programmed previously, otherwise it rejects the student's answer. In the case of the questions this is not a problem because when using help, the answers are presented in a multiple choice way. Therefore, I find the present solution adequate for the time being, but in the future I intend to develop it.

\section{OTHER METHODS SUPPORTING SELF- STUDY}

In addition to the above program, the sample exam and the compulsory homework, a test comprising 30 tasks, also helps student preparation 
and this can be downloaded from the Internet. The total of support material mentioned previously along with it's constant development greatly increases the efficiency of our work. We will continue to aim at developing new and effective methods with the help of tenders or our own resources. Enlarging the initiated material will take place after it has been tested and reviewed it.

\section{CONCLUSION}

The development of multi-media material for internal use can be achieved using own resources. Professional knowledge of programming is not necessarily required, but the assistance of a professional is indispensable even in case of working with a good sample program.
Short, visually rich programs similar to the one introduced above are naturally for use in education primarily based on self-study.

It is my view that the accomplished material may be of great use to students and teachers in secondary professional education, since it requires no advanced mathematical knowledge. Therefore it can be implemented in the scope of the foundation material of economic secondary and higher education.

I request colleagues who have suggestions, questions or any observation to contact me at the correspondance below:

e-mail: avegh@kvif.bgf.hu

telephone: 3613746244

address: 1054 Budapest Alkotmány str. 9-11

\section{REFERENCES}

(1) Hillier-Lieberman (1994): Bevezetés az operációkutatásba (Introduction to Operation Research). LSI, Budapest

(2) Bernát L. (2002): Word szövegszerkesztő mintaprogram 2002 (Word Text Editing Prototype Program 2002).

(3) Operációkutatás elmélet és példatár (1998): Editor: dr. Felber (Operation Research Theory and Exercises), KVIF

(4) Brückner H. (2001): A számítógépek oktatási alkalmazásai tapasztalatok és fejlődési tendenciák ( $\mathrm{PhD}$ értekezés tézisei) (Computer use in Education - experiences and development tendencies)
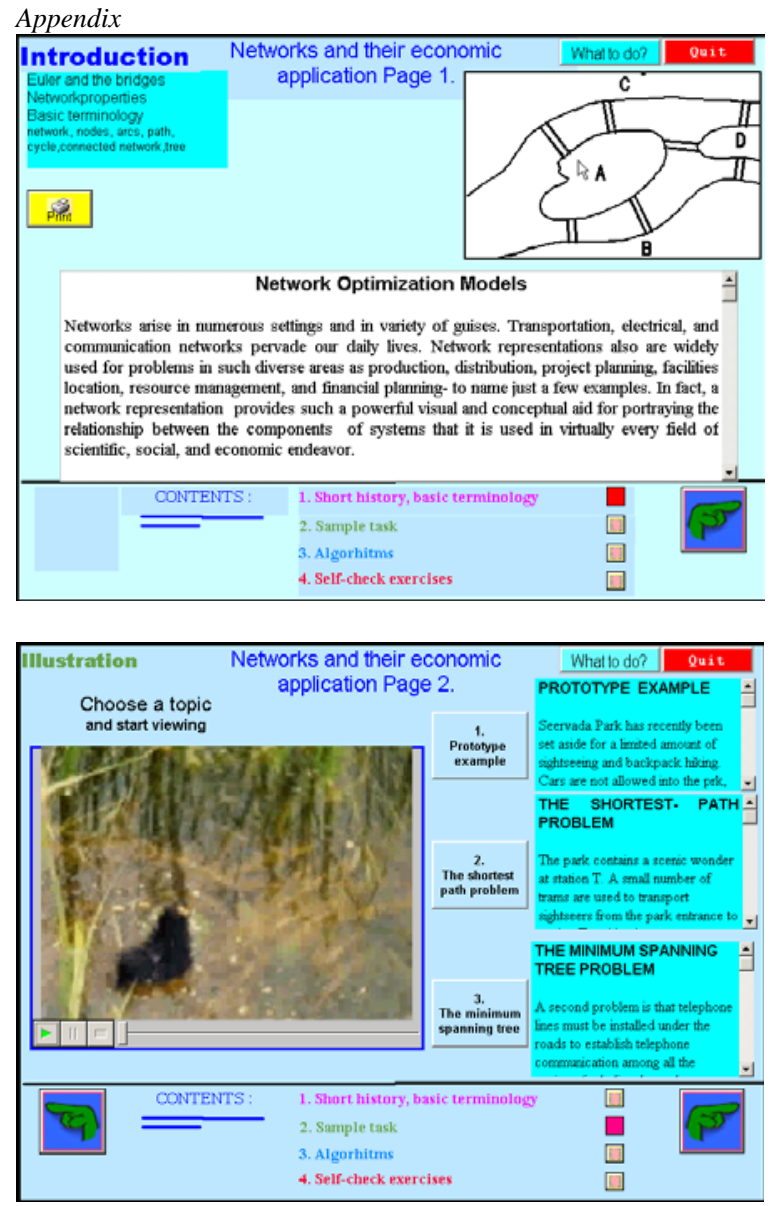

(5) Komenczi B. (1997): ON LINE Az információs társadalom és az oktatás ('Information Society' and education). Új Pedagógiai Szemle, 7.

(6) Z. Karvalics L. (1999): Iskolai hálózatok: a világgazdasági kihívásoktól a versenyelőny tervezésig (School networks: From meeting global economical challenges to the planning of competitive edge). Új Pedagógiai Szemle, 2.
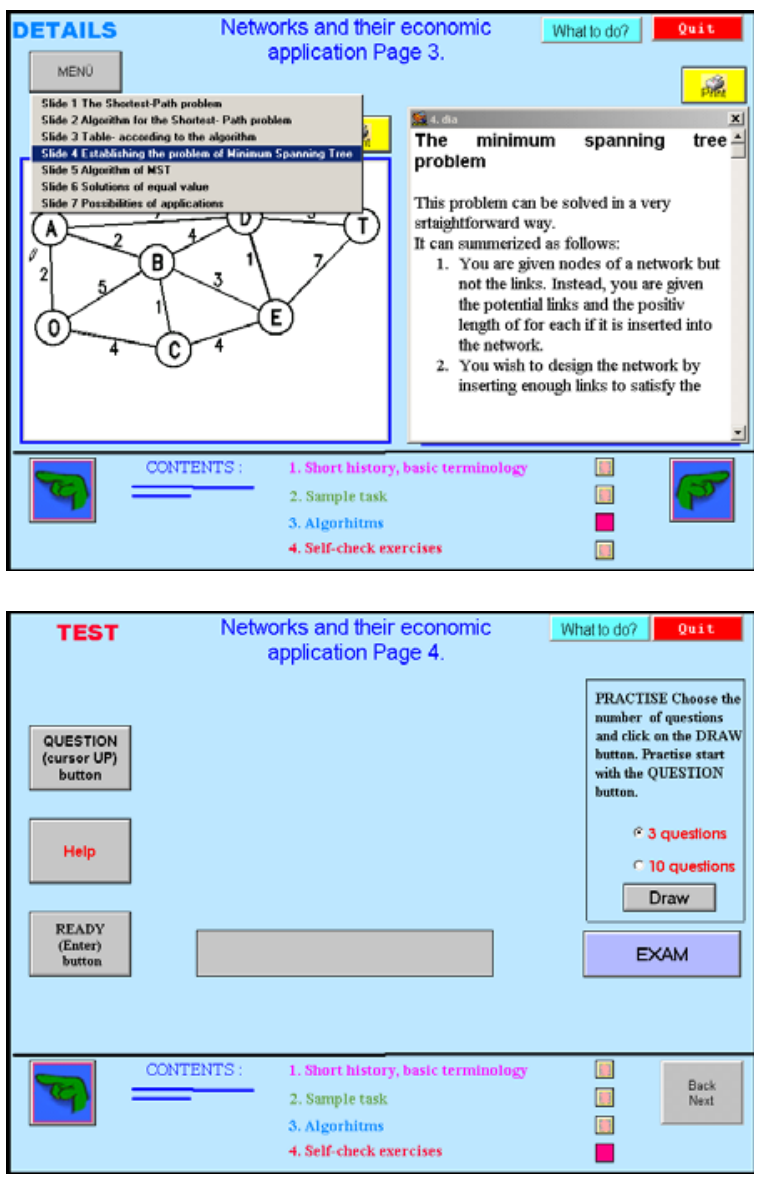